\title{
Pertanggungjawaban Pidana Petugas Lapas yang Terlibat Peredaran Narkotika di Lembaga Pemasyarakatan
}

\author{
Ferdian Rinaldi* \\ Dosen Fakultas Hukum Universitas Lancang Kuning \\ Jalan Yos Sudarso Km 8, Rumbai, Kota Pekanbaru,Indonesia
}

\begin{abstract}
Abstrak
Tujuan penelitian ini: Pertama, menjelaskan pertanggung jawaban pidana petugas Lembaga Pemasyarakatan dalam hal keterkaitan peredaran narkotika di Lembaga Pemasyarakatan. Kedua, menjelaskan upaya apa yang dilakukan Kementerian Hukum dan Hak Asasi Manusia dalam mencegah peredaran narkotika di Lembaga Pemasyarakatan. Metode penelitian yang dilakukan bersifat deskriptif analitis dengan pendekatan yuridis normatif. Hasil penelitian ini dapat dijelaskan petugas Lembaga Pemasyarakatan yang terlibat peredaran narkotika sebagai penanggung jawab penuh yang termasuk kategori medeplager (yang ikut serta). Mereka melakukan peredaran gelap narkotika kebanyakan karena faktor ekonomi dan buruknya mental para petugas. Menyikapi maraknya peredaran narkotika upaya yang telah dilakukan salah satunya peningkatan kualitas petugas Lembaga Pemasyarakatan. Peningkatan kualitas petugas melalui aktivitas program-program revolusi mental, yaitu mengubah mindset petugas pemasyarakatan, mencegah keterlibatan peredaran narkotika di Lembaga Pemasyarakatan. Simpulan penelitian ini: Pertama,Undang-Undang tentang Narkotika dan Peraturan Menteri Hukum dan Hak Asasi Manusia tentang Kode Etik Pegawai Pemasyarakatan tidak ada yang mengatur tentang kewajiban pelimpahan berkas kasus dari majelis kode etik petugas Lembaga Pemasyarakatan ke Kepolisian atau Kejaksaan untuk diproses secara hukum ketika petugas terlibat peredaran narkotika telah dijatuhkan sanksi kode etik. Upaya yang dilakukan oleh Kementerian Hukum dan Hak Asasi Manusia dalam menanggulangi peredaran narkotika di Lembaga Pemasyarakatan telah melakukan upaya dalam bentuk rehabilitasi terhadap pemakai narkotika; mengadakan rotasi rutin bandar narkotika setiap tiga bulan; menempatkan pelacak sinyal agar para bandar tidak leluasa berkomunikasi menjalankan bisnis narkotika; mengadakan penggrebekan rutin setiap bulan; mencopot Kepala Lembaga Pemasyarakatan yang ditempatnya menjadi peredaran narkotika; menjatuhkan hukum seberat-beratnyanya bagi sipir
\end{abstract}

*Penulis korespondensi e-mail: erdianrinaldi@unilak.ac.id 
yang berkolusi dengan bandar narkotika; dan mencegah narkotika dengan pendidikan agama.

\title{
Kata Kunci: Pertanggungjawaban Pidana, Narkotika, Lembaga Pemasyarakatan.
}

\begin{abstract}
The purpose of this study: First, explain the criminal liability of officers of Penitentiary in terms of narcotics circulation in the Correctional Institution. Second, explains what efforts the Ministry of Justice and Human Rights has done in preventing the distribution of narcotics in Penitentiary. The research method is analytical descriptive with normative juridical approach. The results of this study can be explained the officers of Correctional Institutions involved narcotics circulation as the full responsibility that includes the category medeplager (who participated). They conduct illicit drug trafficking mostly due to economic factors and poor mental officers. In response to the rampant circulation of narcotics efforts that have been made one of them improved the quality of prison officers. Improving the quality of officers through the activities of the mental revolution programs, namely changing the prisoner's mindset, preventing the involvement of narcotics circulation in the Penitentiary. Conclusions of this research: Firstly, the Law on Narcotics and the Regulation of the Minister of Justice and Human Rights on the Code of Practice of the Correctional Officers, there is nothing regulating the obligation to transfer the case files from the code of conduct of the officers of the Penitentiary to the Police or Prosecutor's Office to be processed legally when officers involved in the circulation of narcotics have been imposed sanction of ethical code. Efforts undertaken by the Ministry of Law and Human Rights in overcoming drug trafficking in Penitentiary have made efforts in the form of rehabilitation of narcotics users; conduct regular rotation of narcotics every three months; putting a signal tracker so the bandar is not free to communicate in running the narcotics business; held regular monthly raids; dismissing the Head of Correctional Institution in his place of narcotics; to give the law the weight of it to the guards in collusion with narcotics; and prevent narcotics with religious education.
\end{abstract}

Keywords: Criminal Accountability, Narcotics, Penitentiary. 


\section{Pendahuluan}

Kejahatan merupakan masalah yang sangat meresahkan masyarakat. Kejahatan selalu ada di masya-rakat meski tidak pernah diinginkan. Oleh karena itu, Pemerintah harus menga-tasinya, berupa penjatuhan pi-dana atau pemindanaan bagi mereka yang telah terbukti melakukan tindak pidana.

Pelaku kejahatan yang divonis penjara akan ditempatkan di Lembaga Pemasyarakatan. Lembaga ini merupakan institusi teknik di jajaran Kementerian Hukum dan Hak Asasi Manusia. Lembaga Pemasyarakatan menjadi wadah memasyarakatkan kembali setiap orang yang telah melakukan kejahatan. Dalam Pasal 2 Undang-Undang Nomor 15 Tahun 1995 tentang Pemasyarakatan disebutkan bahwa "sistem pemasyarakatan diselenggarakan dalam rangka membentuk warga binaan (warga binaan, anak didik pemasyarakatan dan klien pemasyarakatan) agar menjadi manusia seutuhnya, menyadari kesalahan, memperbaiki diri dan tidak mengulangi tindak pidana sehingga dapat diterima kembali oleh lingkungan masyarakat, dapat aktif berperan dalam pembangunan dan hidup secara wajar sebagai warga yang baik dan bertanggung jawab." Hal ini berarti bahwa pembinaan terhadap warga binaan juga harus bermanfaat, baik selama yang bersangkutan menjalani pidana maupun setelah selesai menjalani pidana, sehingga mereka memiliki kesempatan yang sama dengan anggota masyarakat pada umumnya untuk dapat memberikan konstribusi sebagai anggota masya-rakat yang aktif dan produktif dalam pembangunan bangsa. ${ }^{1}$

Pemikiran mengenai tujuan dari suatu pemidanaan yang dianut orang dewasa ini, sebenarnya bukan merupakan suatu pemikiran yang baru, melainkan sedikit atau banyak telah mendapat pengaruh dari pemikiran para pemikir atau para penulis beberapa abad yang lalu. Mereka mengeluarkan pendapat tentang dasar pembenaran atau tentang rechtvaardigingsground dari suatu pemidanaan, baik yang telah melihat pemidanaan semata-mata sebagai pemidanaan saja, maupun yang mengaitkan pemidanaan dengan tujuan yang ingindicapai ter-hadap pemidanaan itu sendiri. Mengenai tujuan yang ingin dicapai dari pemidanaan ternyata tidak terdapat suatu kesamaan pendapat di antara para penulis. Pada dasarnya Pada dasarnya terdapat tiga pokok pemikiran tentang tujuan yang ingin dicapai dengan suatu pemidanaan, yaitu ${ }^{2}$

1. Untuk memperbaiki pribadi dari penjahat itu sendiri

2. Untuk membuat orang menjadi jera dalam melakukan kejahatan - kejahatan Untuk membuat penjahat tertentu menjadi tidak mampu me-lakukan

3. kejahatan yang lain, yakni penjahat yang dengan cara-cara yang lain sudah tidak dapat diperbaiki lagi. hlm. 92

${ }^{1}$ Dwidja Priyatna, Sistem Pelaksanaan Pidana Penjara di Indonesia, (Bandung, 2005),

${ }^{2}$ P.A.F.Lamintang, Hukum Penintensier, (Jakarta: Sinar Grafika, 2010), hlm. 10-11. 
Pertumbuhan pemikiran mengenai tujuan pemidanaan, seringkali mendorong orang untuk menciptakan lembaga pemidanaan, lembaga penindakan atau lembaga kebijaksanaan yang baru, yang sebelumnya belum pernah dikenal dalam praktik. Agar lembaga itu dapat digunakan secara sah menurut hukum, sudah tentu lembaga-lembaga tersebut harus dituangkan dalam suatu peraturan perundang-undangan.

Sebagai contoh pemikiran tentang melakukan pemidanaan terhadap orang-orang yang memang perlu dipidana, karena melakukan suatu tindakan semata-mata terdorong dengan maksud yang dapat dihormati. Pemikiran seperti itu, ternyata telah mendorong Presiden Republik Indonesia dengan persetujuan Badan Pekerja Komite Nasional Pusat untuk menciptakan suatu jenis pidana pokok yang baru, yaitu pidana tutupan dan telah diaturnya di dalam Undang-undang tanggal 31 Oktober 1946 Nomor 20 tentang Pidana Tutupan.

Hubungan yang erat antara tujuan yang ingin dicapai dalam pemidanaan dengan lembaga pemidanaan, penindakan, dan kebijaksanaan, dapat dilihat secara jelas dalam cara memperlakukan terpidana di Lembaga Pemasyarakatan. Hal ini bila dikaitkan dengan pemikiran orang mengenai pidana, yang tumbuh dalam sejarah, yakni dari pemikiran yang tidak manusiawi hingga pe- mikiran yang menghendaki agar harkat dan martabat terpidana sebagai manusia tetap dihargai, walaupun ia telah melakukan suatu tindakan yang melawanhukum. ${ }^{3}$

Lembaga Pemasyarakatan sebenarnya suatu lembaga, yang dahulu juga dikenal sebagai rumah penjara, yakni tempat di mana orangorang yang telah dijatuhi pidana dengan pidana-pidana tertentu oleh hakim harus menjalankan pidana mereka. Pemberian sebutan yang baru kepada rumah penjara sebagai Lembaga Pemasyarakatan, untuk men-jadikan Lembaga Pemasyarakatan bukan saja sebagai tempat untuk semata-mata memidana orang, melainkan juga sebagai tempat untuk membina atau mendidik orang-orang terpidana, agar mereka setelah selesai menjalankan pidana, mempunyai kemampuan untuk menyesuaikan diri dengan kehidupan di luar Lembaga Pemasyarakatan sebagai warga negara yang baik dan taat pada hukum yang berlaku. Rumusan tentang tujuan dari pidana penjara atau sekarang Lembaga Pemasyarakatan yang diatur dalam Undang-Undang Nomor 12 Tahun 1995 tentang Pemasyarakatan, yakni di-samping menimbulkan rasa derita dari terpidana karena hilangnya kemerdekaan bergerak, membimbing terpidana agar bertobat, mendidik ia menjadi seorang anggota masyarakat sosial Indonesia yang berguna atau dengan perkataan lain, tujuan dari pidan aden-

3/bid,hlm. 22. 
gan perkataan lain, tujuan dari pidana penjara itu ialah pemasyarakatan. Walaupun telah ada gagasan untuk menjadikan tujuan dari pidana penjara itu suatu pemasyarakatan, dan walaupun sebutan dari rumah penjara itu telah diganti dengan Lembaga Pemasyarakatan, akan tetapi dalam praktik ternyata gagasan tersebut tidak didukung oleh suatu konsepsi yang jelas dan sarana-sarana yang memadai. ${ }^{4}$

Secara filosofis pemasyarakatan adalah sistem pemidanaan yang sudah jauh bergerak meninggalkan filosofi retributive (tindakan pembalasan), deterrence (penjeraan) dan juga resosialiasi. Dengan kata lain, pemidanaan tidak ditujukan untuk membuat derita sebagai bentuk pembalasan, tidak ditujukan untuk membuat jera dengan penderitaan, dan juga tidak mengasumsikan terpidana sebagai seseorang yang kurang sosialisasinya. Pemasyarakatan sejalan dengan filosofis reintegrasi sosial yang berasumsi kejahatan adalah konflik yang terjadi antara terpidana dengan masyarakat. Sehingga pemidanaan ditujukan untuk memulihkan konflik atau juga menyatukan kembali terpidana dengan masyarakatnya atau reintegrasi. $^{5}$

Fungsi Lembaga Pemasyarakatan yang dicita-citakan menjadi tidak sesuai harapan. Terutama dengan perkembangan peredaran narkotika di dalam Lembaga Pemasyar- akatan. Fenomena ini telah menimbulkan rasa kekhawatiran yang mendalam. Karena hal ini terkait keterlibatan oknum petugas Lembaga $\mathrm{Pe}$ masyarakatan yang justru membantu peredaran narkotika. Salah satu contoh Lembaga Pemasyarakatan Banceuy. Badan Narkotika Nasional (BNN) pernah menemukan peredaran narkotika di Lembaga Pemasyarakatan itu. BNN mensinyalir keterlibatan oknum petugas Lembaga Pemasyarakatan membantu peredaran paket sabu-sabu. Tidak mungkin paket sabu-sabu bisa masuk Lembaga Pemasya - rakatan Banceuy tanpa sepengetahuan petugas.

Menanggapi hal itu Kantor Wilayah Kementrian Hukum dan Hak Asasi Manusia Provinsi Jawa Barat sepakat dengan BNN untuk melakukan tes urine terhadap semua penghuni Lembaga Pemasyarakatan baik dari kalangan narapidana maupun petugas. Apabila ditemukan narapidana yang positif menggunakan sabu-sabu maka kasusnya akan disidik lagi darimana barang narkotika tersebut ditemukan, sedangkan bila petugas kedapatan positif maka yang bersangkutan akan langsung diberhentikan secara tidak hormat. $^{6}$

Sejatinya Lembaga Pemasyarakatan tempat untuk melakukan pembinaan. Akan tetapi, justru sebaliknya lembaga pemasyarakatan justru di jadikan tempat peredaran narkotika.

\footnotetext{
${ }^{4} \mathrm{Ibid}, \mathrm{hlm} .165-166$.

${ }^{5}$ Direktorat Jenderal Pemasyarakatan, 40 Tahun Pemasyarakatan: Mengukir Citra Profesionalisme, (Jakarta: Direktorat Jenderal Pemasyarakatan, 2010), hlm. 11.

${ }^{6}$ 2,3 gram sabu ditemukan di Lapas Banceuy Bandung napi sipir di tes urine, www.detiknews.com, diakses pada tanggal 27 November 2017.
} 
Terungkapnya peredaran nar-kotika yang melibatkan aparat pen-egak hukum sendiri menambah daf-tar panjang buruknya sistem Lemba-ga Pemasyarakatan. Maraknya peredaran narkotika di Lembaga Pemasya-rakatan secara garis besar disebabkan dua masalah, yaitu pertama, persoalan Sumber Daya Manusia (SDM) petugas Lembaga Pemasyarakatan dan kedua, sistem Lembaga Pemasyarakatan. Bobroknya mental SDM, sudah bukan menjadi rahasia umum mudahnya narkotika masuk karena adanya permainan uang yang melibatkan petugas dan pejabat Lembaga $\mathrm{Pe}$ masyarakatan sebagai pengedar. Lembaga Pemasyarakatan pernah menjadi pusat kendalipara bandar narkotika, bahkan narapidana narkotika dengan leluasa berpesta narkotika. Hal ini karena keterlibatan petugas Lembaga Pemasyarakatan.

Hal ini sangat memprihatinkan, kar-ena melenceng dari tujuan Lembaga Pemasyarakatan. Sebagaimana disinggung tujuan Lembaga Pemasyarakatan adalah membentuk warga binaan pemasyarakatan agar menjadi manusia seutuhnya, menyadari kesalahan, memperbaiki diri dan tidak mengulangi tindak pidana sehingga dapat diterima kembali oleh lingkungan masyarakat, dapat aktif berperan dalam pembangunan dan dapat hidup secara wajar sebagai warga negara yang baik dan ber-tanggung jawab. ${ }^{7}$
Lembaga Pemasyarakatan dianggap sangat steril dari jangkauan petugas lain apalagi mental oknum petugas Lembaga Pemasyarakatan sangat mudah dipengaruh. Terpidana narkotika menjadi leluasa hanya berbekal alat komunikasi maka transaksi bisa dilakukan aktivitasnya pun menjadi lebih mudah dan strategis. Sepak terjang terpidana narkotika di Lembaga Pemasyarakatan sudah jadi barang mainan oknum petugas Lembaga Pemasyarakatan mereka bisa mendapatkan keuntungan dari aktivitas tersebut.

Sikap tidak tegas pemerintah diperlukan untuk memberlakukan vonis mati. Pelaksanaan eksekusi mati dapat membuat shock terapi bagi para terpidana narkotika lainnya, setidaknya ini dapat menekan dan diminimalisir. ${ }^{8}$

Penelitian hukum terkait peredaran narkotika di Lembaga Pemasyarakatan pernah disinggung penulis lain. Fuzi Narindrani pernah menelititentang "Sistem Hukum Pencegahan Peredaran Nar-kotika di Lembaga Pemasya-rakatan"(Studi Kasus di LembagaPemasyarakatan Cipinang), yang dimuat dalam jurnal Recht Vinding Volume 6 Nomor 1 Tahun 2017.Dalam penelitiannya dijelaskan bahwa peredaran narkotika terutama Lembaga Pemasyarakatan sudah marak, hal ini merupakan dampak dari hilangnya kontrol sistem hukum yang ada. Kondisi tersebut dari hilangnya kon-

${ }^{6}$ 2,3 gram sabu ditemukan di Lapas Banceuy Bandung napi sipir di tes urine, www.detiknews.com, diakses pada tanggal 27 November 2017.

${ }^{7}$ Maraknya perdaran narkotika di lapas seluruh Indonesia, www.vivanews.com, diakses 27 November 2017.

${ }^{8}$ Peredaran narkotika di Indonesia, www.okezone.com, diakses 27 November 2017. 
trol sistem hukum yang ada. Kondisi tersebut berdampak pada terbentuknya pandangan negatif masyarakat terhadap pelaksanaan penegakan hukum di Indonesia terutama di lingkungan institusi pemasyarakatan. Untuk itu, diperlukan suatu upaya dan langkah nyata terhadap penang-ulangan dan pemberantasan peredaran narkotika di dalam Lembaga Pemasyarakatan melalui perubahan sistem hukum. ${ }^{9}$

Lebih lanjut Fuzi Narindrani menjelaskan bahwa sistem hukum pencegahan peredaran narkotika dalam mewujudkan keadilan untuk kedamaian di Lembaga Pemasyarakatan terus dibangun. Peredaran narkotika di Lembaga Pemasyarakatan merupakan dampak dari hilangnya kontrol sistem hukum. Hal ini ditandai dengan kondisi sistem hukum berupa legalstructure, legal substance dan legal culture yang sudah sangat mengkhawatirkan. $\mathrm{Na}$. mun, masih ada secercah harapan upaya mewujudkan keadilan untuk kedamaian di Lembaga Pemasyarakatan berupa rehabilitasi, terapi metadon, penghargaan bagi petugas maupun pembentukan peraturan. Oleh sebab itu, disarankan kepada Kementerian Hukum dan Hak Asasi Manusia untuk memperbaiki sistem hukum baik legalstructure, legal substance maupun legal culture. ${ }^{10}$

Penelitian Fuzi Narindrani mempunyai persamaan dan perbedaan dengan penelitian ini. Persamaannya, kedua penelitian samasama meneliti mengenai peredaran na. rkotika di Lembaga Pemasyarakatan. Perbedaannya, jika penelitian Fuzi Narindrani meneliti mengenai sistem hukum pencegahan peredaran narkotika di Lembaga Pemasyarakatan, sedangkan penelitian ini meneliti pertanggung jawaban pidana petugas Lembaga Pemasyarakatan yang terlibat peredaran narkotika. Selain itu perbedaan lainnya, penelitian Fuzi Narindrani menggunakan metode yuridisempiris, sedangkan pada penelitian yang akan dilakukan menggunakan metode penelitian hukum normatif.

Haryanto Dwiatmojo melakukan penelitian dengan judul "Pelaksanaan Pidana dan Pembinaan $\mathrm{Na}$ rapidana Tindak Pidana Narkotika" (Studi terhadap Pembinaan Narapidana diLembaga Pemasyarakatan Nar-kotika Klas IIA Yogyakarta), dimuat dalam jurnal Perspektif, Volume XVIII, Nomor 2, Tahun 2013. Penelitiannya bertujuan:

Pertama, pembinaan yang dilakukan di Lembaga Pemasyarakatan Narkotika Klas IIA Yogyakarta kurang maksimal. Namun, penangannya telah sesuai dengan Undangundang Nomor 12 Tahun 1995 tentang Pemasyarakatan, yang mana pelaksanaannya diatur dengan Peraturan Pemerintah Nomor 31 Tahun 1999 tentang Pembinaan dan Pembimbingan Warga Binaan Pemasyarakatan. Lembaga Pemasyarakatan Narkotika Klas IIA Yogyakarta juga telah memenuhi hak-hak dari para narapidana. Sehingga tujuan sistem pema arakatan dapat dicapai, yaitu

\footnotetext{
${ }^{9}$ Fuzi Narindrani, Sistem Hukum Pencegahan Peredaran Narkotika di Lembaga Pemasyarakatan, Jurnal Recht Vinding, Volume 6, Nomor 1, Mei 2017, hlm. 45.

${ }^{10}$ lbid.
} 
membentuk warga binaan pemasyarakatan agar jadi manusia yang seutuhnya, menyadari kesalahannya, memperbaiki diri, dan juga tidak mengulangi lagi tindak pidana sehingga bisa diterima kembali oleh lingkungan masyarakat, berperan aktif dalam hal pembangunan serta hidup secara wajar sebagai warga yang baik dan bertanggungjawab.

Kedua, dalam proses pelaksanaan pembinaan narapidana terdapat beberapa hambatan, yaitu

1. Jumlah petugas medis yang dirasa masih kurang, karena masalah rehabilitasi kesehaan merupakan masalah yang harus diterapkan kepada narapidana narkotika, dan narapidana narkotika rentan terhadap penyakit.

2. Partisipasi narapidana dalam pembinaan rendah, diketahui berapa narapidana malas-malasan dan belum menyadari pentingnya pembinaan bagi mereka.

3. Beberapa program pembinaan, sudah siap untuk dapat dijalankan, namun masih terkendala ruangan yang terbatas, kegiatan kerja yang sudah baik terhambat oleh keterbatasan lahan, terutama lahan perkebunan dan perikanan.

4. Minimnya anggaran biaya kegiatan pembinaan untuk seluruh kegiatan pembinaan yang sudah diprogramkan Lem- baga Pemasyarakatan Narkotika mengharuskan kerjasama dengan pihak lain agar dapat menjalankan pembinaan dengan baik, dana yang ada harus digunakan efisien dan efektif agar pembinaan tetap berjalan dengan baik.

5. Stigma masyarakat terhadap narapidana itu masih sangat buruk terlihat hanya sedikit saja masyarakat yang ikut membantu dalam program pembinaan, kebanyakan masyarakat acuh tak acuh dalam proses ini, padahal partisipasi masyarakat sangatlah diperlukan dalam program pembinaan karena setelah bebas perhatian masyarakat kepada para mantan narapindana tetap diperlukan agar mereka tidak terasing. ${ }^{11}$

Nizar Apriansyahpernah meneliti dengan judul "Peningkatan Kemampuan Petugas Pemasyarakatan Dalam Me-nanggulangi Peredaran Narkoba di Lembaga Pemasyarakatan dan Rumah Tahanan Negara" dimuat dalam jurnal De Jure Voleme 16, Nomor 4, Desember 2016. Penelitiannya menjelaskan banyaknya permasalahan di Lembaga Pemasyarakatan, menjadi sumber pemberitaan media yang negatif tentang Lembaga

Pemasyarakatan dan Rumah Tahanan Negara sebagai sarang narkoba. Penelitiannya berusaha mendapatkan fakta terkait dengan

\footnotetext{
${ }^{1}$ Haryanto Dwiatmojo, Pelaksanaan Pidana dan Pembinaan Narapidana Tindak Pidana Narkotika (Studi terhadap Pembinaan Narapidana di Lembaga Pemasyarakatan Narkotika Klas IIA Yogyakarta), Jurnal Perspektif, Volume XVIII, Nomor 1, Mei 2013, hIm. 76.
} 
banyaknya kasus peredaran narkoba diLembaga Pemasyarakatan dan Rumah Tahanan Negara. Dengan maksud untuk mencari tahu pola yang dapat diterapkan untuk mendidik petugas pemasyarakatan, agar kedepan dapat diambil langkahlangka strategis di Kementerian Hukum dan Hak Asasi Manusia. Metode penelitian dengan mengunakan pendekatan kualitatif dan pendekatan kuantitatif. Hasil penelitiannya menyimpulkan bahwa Pemerintah sudah berusaha meningkatkan kemampuan petugas Lembaga Pemasyarakatan dan Rumah Negara dengan cara melakukan interaksi antar pimpinan dan bawahan yang memiliki arti supervisi dan tangung jawab serta kesempatan karier yang jelas. Selain itu juga tentang kesejahteraan ekonomi, seperti remunerasi, tunjangan dan lain-lain. Inilah salah satu bentuk apresiasi pemerintah dalam membina petugas agar kinerja-nya lebih optimal. Hambatan diLembaga Pemasyarakatan diantaranya kurangnya tenaga teknis pemasyarakatan terutama lulusan Akademi IImu Pemasyarakatan dan kurangnya tenaga sipir dibandingkan dengan jumlah penghuni serta SDM tenaga pemasyarakatan yang minim karena sistem perekrutan yang tidak didasari oleh kebutuhan kualifikasi personil, keterbatasan sarana perasana pendukung, seperti senjata api, borgol dan alat pemantau pendukung CCTV. ${ }^{12}$

Penelitian Nizar Apriansyah tersebut mempunyai persamaan dan perbedaan dengan penelitian ini. Persamaannya, kedua penelitian samasama meneliti peredaran narkotika di Lembaga Pemasyarakatan. Perbedaannya, jika penelitian Nizar Apriansyah meneliti Mengenai peningkatan kemampuan petugas pemasyarakatan dalam menangulangi peredaran narkoba di Lembaga Pemasyarakatan dan Rumah Tahanan Negara, sedangkan pada penelitian ini meneliti pertanggung jawaban pidana petugas Lembaga Pemasyarakatan yang terlibat peredaran narkotika di Lembaga Pemasyarakatan.

Penyalahgunaan dan peredaran narkotika di Lembaga Pemasyarakatan merupakan masalah serius dan fakta yang tidak dapat dipungkiri. Oleh karena itu diperlukan upaya untuk pencegahan dan pemberantasan penyalahgunaan dan pe redaran narkotika. ${ }^{13}$ Dari penelitian terdahulu yang diuraikan diatas maka dapat dikatakan penelitian ini berbeda substansinya. Oleh karena itu, penelitian ini merupakan sesuatu yang baru atau berbeda dengan penelitian terdahulu (novelty). Tujuan dari penelitian ini, yaitu Pertama, menjelaskan pertanggung jawaban pidana petugas Lembaga Pemasyarakatan dalam hal keterkaitan peredaran narkotika di Lembaga Pemasyarakatan.

Kedua, menjelaskan upaya apa yang dilakukan Kementerian Hukum dan Hak Asasi Manusia dalam mencegah peredaran narkotika di Lembaga Pemasyarakatan.

\footnotetext{
${ }^{12}$ Ibid.

${ }^{13}$ Muhamad Amin Imran, Hubungan Fungsional Badan Narkotika Nasional dengan Lembaga Pemasyarakatan Dalam Penanganan Narkotika di Lembaga Pemasyarakatan, Jurnal IUS, Volume I, Nomor 2, Agustus 2013, hlm.328.
} 


\section{Metode Penelitian}

Metode penelitian sangat penting dalam rangka memperoleh hasil penelitian yang memuaskan dan akurat, oleh karena itu penulis melakukan penelitian berdasarkan metode sebagai berikut.

\section{Metode pendekatan}

Metode pendekatan penelitian ini yuridis normatif, yaitu metode yang mempelajari dan meneliti bahanbahan hukum primer dan bahan-bahan hukum sekunder yang secara deduktif menganalisis terhadap pasal-pasal, peraturan perundang-undangan, serta asas, teori, dan konsepsi dari para sarjana yang menjelaskan tentang hal-hal terkait dengan penelitian yang dilakukan penulis.

\section{Spesifikasi penelitian}

Spesifikasi penelitian bersifat deskriptif analitis, yaitu menggambarkan dan menerangkan secara jelas mengenai permasalahan peredaran narkotika di Lembaga Pemasyarakatan yang melibatkan petugas.

\section{Pembahasan Pertanggung jawab- an Petugas Lembaga Pemasyara- katan yang Terlibat Peredaran Narkotika di Lembaga Pemasya- rakatan}

Peredaran narkotika di Lembaga Pemasyarakatan yang melibatkan petugas sanksi kode etik dapat dikenakan terhadap petugas yang terlibat. Sanksi tersebut dapat berupa diberhentikan secara tidak hormat. Penjatuhan sanksi tersebut diperlukan buktimelalui sidang kode etik oleh majelis kode etik berdasarkan pengaduan, temuan dan lapkan pengaduan, temuan dan laporan. Setelah sanksi etik dijatuhkan terhadap petugas Lembaga Pemasyarakatan yang terlibat peredaran narkotika maka majelis kode etik dapat melimpahkan kasus tersebut ke Kepolisian untuk di proses secara hukum.

Pertanggung jawaban pidana menjurus kepada pemidanaan petindak, jika telah melakukan suatu tindak pidana dan memenuhi unsur-unsur yang ditentukan undang-undang. Dilihat dari sudut terjadinya suatu tindakan yang terlarang (diharuskan), seseorang akan dipertanggung jawab-pidanakan atas tindakantindakan tersebut. Apabila tindakan tersebut bersifat melawan hukum (dan tidak ada peniadaan sifat melawan hukum atau rechtsvaardigingsgrond atau alasan pembenar) untuk itu. Kemudian dilihat dari sudut kemampuan bertanggung jawab ma ka hanya seseorang yang mampu bertanggung jawab yang dapat dipertanggung jawabkan. Dikatakan seseorang mampu bertanggung jawab (toerekeningsvatbaar).

Dalam bukunya Asas-Asas Hukum Pidana di Indonesia dan Penerapannya E.Y. Kanter dan S.R. Sianturi menjelaskan bahwa unsur mampu bertanggung jawab mencakup:

1. Keadaan jiwanya.

a. Tidak terganggu oleh penyakit terusmenerus atau sementara (te-mporair).

\footnotetext{
${ }^{14}$ Rony Hanitijo Soemitro, Metodologi Penelitian Hukum, (Jakarta: Ghalia Indonesia, 2012), hlm. 98.

${ }^{15}$ E. Y Kanter \& S.R. Sianturi, Asas-asas Hukum Pidana di Indonesia dan Penerapannya, (Jakarta: Storia Grafika, 2002, hlm. 84.
} 
b. Tidak cacat dalam petumbuhan (gagu, idiot, imbecile, dan sebagainya)

c. Tidak terganggu karena terejut, hypnotisme, amar-ah yang meluap, pengaruh bawah sadar/reflexe bewenging, melindur/slaapwandel, mengigau karena demam /koorts, nyidamdan lain sebagainya. Dengan perkataan lain dia dalam keadaan sadar.

2. Kemampuan jiwanya.

a. Dapat menginsyafi hakekat dari tindakannya.

b. Dapat menentukan kehendaknya atas tindakan tersebut, apakah akan dilaksanakan atau tidak.

c. Dapat mengetahui ketercelaan dari tindakan tersebut.

Dalam hal pertangggung jawaban pidana petugas Lem-baga Pemasyarakatan yang terlibat dalam kasus peredaran narkotika yang penulis teliti ternyata hal ini terkait dengan prinsip penyertaan. Dalam hal penyertaan, dapat diklasifi-kasikan atas dua bentuk, yaitu ${ }^{16}$

1. Penanggung jawab penuh Maksudnya orang yang menyebabkan (turut serta menyebabkan) peristiwa pidana tersebut dan diancam dengan pidana setinggi pidana pokoknya. Ter-masuk kategori pennggung jawab penuh sebagai berikut. a. Dader (pembuat) adalah penanggung jawab pidana atau orang yang sikap tindaknya memenuhi semua unsur yang disebut dalam perumusan tindak pidana baik berupa delik materil mau-pun formil.

b. Dadere (pembuat) adalah penanggung jawab pidana atau orang yang sikap tindaknya memenuhi semua unsur yang disebut dalam perumusan tindak pidana baik berupa delik materil maupunformil.

c. Mededader dan medeplager (yang turut serta) adalah orang yang menjadi kawan pelaku dan medeplager orang yang ikut serta melakukan tindak pidana. Perbedaannya terletak pada peranan orang-orang yang menciptakan /menyebabkan peristiwa pidana tersebut.

d. Doenplager (yang menyuruh melakukan) adalah seseorang yang menyuruh orang lain untuk melakukan suatu peristiwa pidana.

e. Uitlokker (penganjur) adalah orang yang membujuk orang lain agar melakukan peristiwa pidana atau dinamakan juga perencana intelectueel dader dan orang yang dibujuk adalah uitgelokte.

\footnotetext{
2011), hlm.132..

${ }^{16}$ Erdianto, Hukum Pidana Indonesia: Suatu Pengantar, (Bandung: Refika Aditama,
} 
2. Penanggung jawab sebagian Maksudnya apabila seseorang bertanggung jawab atas bantuan percobaan suatu kejahatan yang diancam dengan pidana sebesar $2 / 3$ pidana kejahatan yang selesai. Termasuk dalam kategori ini meliputi poger, yaitu orang yang melakukan poging (percobaan).

Berdasarkan analisis pe-nulis bahwa petugas Lembaga Pemasyarakatan yang terlibat peredaran narkotika adalah sebagai penanggung jawab penuh yang termasuk kategori medeplager (yang ikut serta).

Petugas Lembaga Pemasyarakatan dalam hal keterkaitan atau keikutsertaan dalam suatu mata rantai peredaran narkotika dalam hal ini tidak dapat disebut pelaku utama karena peranannya hanya ikut serta atau uitgelokte (orang yang dibujuk).

Menurut penulis semua rangkaian peristiwa dalam peredaran narkotika di Lembaga Pemasyarakatan yang melibatkan petugas lapas dilatarbelakangi oleh motivasi untuk mencari keuntungan materil. Mereka melakukan peredaran gelap narkotika kebanyakan karena faktor ekonomi dan buruknya mental para petugas. Dalam hal pertanggung jawaban pidana yang dijatuhkan terhadap petugas Lembaga Pemasyarakatan yang terlibat peredaran narkotika kebanyakan dijatuhi Pasal 112 ayat (2) juncto Pasal 132 ayat (1) dan Pasal 114 ayat (2) UndangUndang Nomor 35 Tahun 2009 tentang Narkotika dengan ancaman hukuman maksimal pidana mati.
Upaya yang Dilakukan Kementerian Hukum dan Hak Asasi Manusia Dalam Pencegahan Peredaran Narkotika di Lembaga Pemasyarakatan

Walaupun terdapat ketentuan hukum yang mengatur mengenai masalah peredaran narkoba di Indonesia, yaitu Undang-Undang Nomor 35 Tahun 2009, namun pada kenyataannya sanksi dalam undang-undang tersebut belum maksimal dalam menangani masalah penyalahgunaan narkotika. Hal ini dapat dibuktikan dengan banyaknya peredaran narkotika di Indonesia salah satunya di Lembaga Pemasya-rakatan.

Mengenai upaya pencegahan peredaran narkotika di Lembaga Pemasyarakatan terdapat upaya yang dapat dilakukan Kementerian Hukum dan Hak Asasi Manusia, sebagai berikut.

1. Pusat rehabilitasi pemakai narkotika Menyiapkan pusat rehabilitasi khusus narkotika adalah salah satu solusi. Mereka membutuhkan proses penyembuhan dari ketergantungan obat terlarang tersebut. Mempenjarakan bukanlah solusi yang tepat bagi permasalahan ini. Menahan, tetapi juga melakukan terapi medis barulah akan berhasil. Bukanlah rahasia lagi banyak pemakai obat yang di Lembaga Pemasyarakatan, tetapi masih ketergantungan obat. Ini disebabkan mereka hanya ditahan secara fisik, tetapi penyakitnya belum sembuh. Mereka itu butuh pengobatan yang sel- 
ama ini tidak maksimal didapatkan. Mereka yang di dalam lambaga pemasya - rakatan dalam kondisi ketergantungan obat sebaiknya memang mendapatkan terapi medis yang tepat dan direhabilitasi sehingga bukannya berada pada lingkungan sesamanapi yang masih ketergantungan obat seperti sekarang ini. Kondisi ini justru dapat memperparah keadaan ketergantungan mereka pada obat. Biasanya juga para pemakai obat juga seringkali kambuhan atau kembali memakai kalau memang di dalam dirinya tidak benar-benar ingin sembuh. Hal ini seringkali disebabkan karena faktor lingkungan mereka yang biasanya diajak oleh sesama pemakai. Pembangunan pusat rehabilitasi khusus narkoba diperlukan di Indonesia sehingga mereka dapat penanganan yang tepat.

2. Mengadakan rotasi rutin bandar narkotika setiap tiga bulan ke Lembaga Pemasyarakatanlain agar mereka tidak menjadi raja kecil dan menjadi sumber uang bagi oknum tertentu di Lembaga Pemasyarakatan.

3. Menempatkan pelacak sinyal agar para bandar tidak bisa menggunakan ponsel, skype ataupun internet yang diduga untuk menjalankan bisnis narkotikanya.

4. Mengadakan peng-grebekan rutin setiap bulannya, itu salah satu cara terampuh untuk memberantas peredaran nar- kotika di Lembaga Pemasyarakatan.

5. Sebaiknya Kepala Lembaga Pemasya-rakatan yang ditempatnya ada peredaran narkotika sebaiknya dicopot.

6. Hukum seberat-beratnya sipir yang berkolusi dengan bandar narkotika.

7. Cegah narkotika dengan pendidikan agama.

Menyikapi maraknya peredaran narkotika di Lembaga Pemasyarakatan Menteri Hukum dan Hak Asasi Manusia Yasonna H. Laoly menyampaikan ber-bagai langkah dan upaya yang telah dilakukan oleh Kementerian Hukum dan Hak Asasi Manusia. Salah satunya peningkatan kualitas petugas Lembaga Pemasyarakatan. Pening-katan kualitas petugas melalui aktivitas program-program revolusi mental, yaitu mengubah mindset petugas pemasyarakatan, mencegah keterlibatan peredaran narkotika di Lembaga Pemasyarakatan. Dari pernyataan tersebut menurut penulis Kementerian Hukum Dan Hak Asasi Manusia tidak cukup merubah mindset petugas Lembaga Pemasyarakatan. Jangan hanya benahi mindset petugas, tetapi juga kitchen set petugas. Kitchen set itu dapur, maksudnya kesejahteraan.

Kesejahteraan petugas Lembaga Pemasyarakatan juga perlu diperhatikan dan dibenahi agar alasan faktor ekonomi tidak lagi menjadi alasan utama. Peredaran narkotika tidak akan berhasil tanpa didukung pembenahan dari sisi kesejahteraan petugas. Selain itu, terobosan-terobosan lain juga dibutuhkan untuk membenahi permasal- 
ahan - permasalahan yang ada di da-lam lapas. ${ }^{17}$

\section{Simpulan}

1. Undang-Undang tentang Narkotika dan Peraturan Menteri Hukum dan Hak Asasi Manusia tentang Kode Etik Pegawai Pemasya-rakatan, tidak ada yang mengatur tentang kewajiban pelimpahan berkas kasus dari majelis kode etik petugas Lembaga Pemasyarakatan ke Kepolisian atau Kejaksaan untuk diproses secara hukum ketika petugas terlibat peredaran narkotika telah dijatuhkan sanksi kode etik. Oleh karena itu, perlu ada peraturan yang mengatur tentang kewajiban pelimpahan berkas atau kasus tersebut kepada pihak Kepolisian untuk diproses secara hukum yang berlaku agar petugas Lembaga Pemasyarakatan yang terlibat peredaran narkotika dapat dipertanggung jawabkan secara pidana.

Semua kasus peredaran narkotika di Lembaga Pemasyarakatan terungkap dariupaya pihak Kepolisian dan BNN dalam mengungkap kasus peredaran narkotika.

2. Undang-Undang tentang Narkotika dan Peraturan Menteri Hukum dan Hak Asasi Manusia tentang Kode Etik Pegawai Pemasyarakatan, tidak ada yang mengatur tentang kewajiban pelimpahan berkas kasus dari majelis kode etik petugas Lembaga Pemasyarakatan ke Kepolisian atau

3. Kejaksaan untuk diproses secara hukum ketika petugas te-rlibat peredaran narkotika telah dijatuhkan sanksi kode etik.Oleh karena itu, perlu ada peraturan yang mengatur tentang kewajiban pelimpahan berkas atau kasus tersebut kepada pihak Kepolisian untuk diproses secara hukum yang berlaku agar petugas Lembaga Pemasyarakatan yang terlibat peredaran narkotika dapat dipertanggung jawabkan secara pidana. Semua kasus peredaran narkotika di Lembaga

Pemasyarakatanterungkap dariupaya pihak Kepolisian dan BNNdalam meng-ungkap kasus peredaran narkotika.

4. Upaya yang dilakukan oleh Kementerian Hukum dan Hak Asasi Manusia dalam menanggulangi peredaran narkotika di Lembaga Pemasyarakatan telah melakukan upaya dalam bentuk rehabilitasi terhadap pemakai narkotika; mengadakan rotasi rutin bandar narkotika setiap tiga bulan; menempatkan pelacak sinyal agar para bandar tidak lelu-

${ }^{17}$ Eka Andri Prasetyo, Peredaran Narkotika di Lapas Kelas IIA Pontianak Ditinjau Dari Sudut Kriminologi, Skripsi Sarjana Hukum, Fakultas Hukum Universitas Tanjungpura, Februari 2013, hlm. 34. 
asa berkomunikasi menjalankan bisnis narkotika; mengadakan penggrebekan rutin setiap bulan; mencopot Kepala Lembaga

5. Pemasyarakatan yang di-tempatnya menjadi peredaran narkotika; menjatuhkan hukum seberat-beratnyanya bagi sipir yang berkolusi dengan bandar narkotika; dan mencegah narkotika dengan pendidikan agama.

\section{Saran}

1. Sebaiknya peredaran narkotika di dalam Lembaga Pemasyarakatan harus ditindak secara tegas mulai dari pelaku yang memakai narkotika sampai petugas yang terlibat.

2. Pemerintah dalam hal ini Kementerian Hukum dan Hak Asasi Manusia sebaiknya bekerja sama dengan BNN secara rutin mengunjungi Lembaga Pemasyarakatan yang diduga atau patut diduga sebagai tempat peredaran narkotika.

\section{Referensi}

DirektoratJenderal Pemasyarakatan. 2010. 40Tahun Pemasyarakatan: Mengukir Citra Profesionalisme. Jakarta: Direktorat Jenderal Pemasyara-katan.

Dwidja Priyatna. 2005.Sistem Pelaksanaan Pidana Penjara di Indonesia. Bandung.

Eka Andri Prasetyo. Peredaran Narkotika di Lapas Kelas IIA Pontianak Ditinjau Dari
Sudut Kriminologi. Skripsi Sarjana Hukum. FakultasHukum Universitas Tanjungpura. Februari 2013.

Erdianto. 2011. Hukum Pidana Indonesia: Suatu Pengantar. Bandung: Refika Aditama.

E.Y Kanter \& S.R. Sianturi. 2000. Asas-asas Hukum Pidana di Indonesia dan Penerapannya. Jakarta: Storia Grafika.

Fuzi Narindrani. Sistem Hukum Pencegahan Peredaran Narkotika di Lembaga Pemasyarakatan. Jurnal Recht Vinding.Volume 6. Nomor 1. Mei 2017.

Haryanto Dwiatmojo. Pelaksanaan

Pidana dan Pembinaan Narapidana Tindak Pidana Narkotika (Studi terhadap Pembinaan Narapidana di Lembaga Pemasyarakatan Narkotika Klas IIA Yogyakarta). Jurnal Perspektif. Volume XVIII. Nomor 1. Mei 2013.

Muhamad Amin Imran. Hubungan Fungsional Badan Narkotika Nasional dengan Lembaga Pemasyarakatan Dalam Penanganan Narkotika di Lembaga Pemasyarakatan.Jurnal IUS. Volume I. Nomor 2. Agustus 2013.

P.A.F.Lamintang. 2010. Hukum Penintensier. Jakarta: Sinar Grafika.

Rony Hanitijo Soemitro. 2012. Metodologi Penelitian Hukum. Jakarta: Ghalia Indonesia. 